\title{
Typing of avian pathogenic Escherichia coli strains by REP-PCR ${ }^{1}$
}

\author{
Marcelo Brocchi ${ }^{2,4}$, Alessandra Ferreira ${ }^{2}$, Marcelo Lancellotti ${ }^{2}$, Eliana G. Stehling ${ }^{2}$, \\ Tatiana A. Campos ${ }^{2}$, Gerson Nakazato ${ }^{2}$, Antonio F. Pestana de Castro ${ }^{3}$ and \\ Wanderley D. Silveira ${ }^{2 *}$
}

\begin{abstract}
Brocchi M., Ferreira A., Lancellotti M., Stehling E.G., Campos T.A., Nakazato G., Pestana de Castro A.F. \& Silveira W.D. 2006. Typing of avian pathogenic Escherichia coli strains by REPPCR. Pesquisa Veterinária Brasileira 26(2):69-73. Departamento de Microbiologia e Imunologia, Instituto de Biologia, Universidade de Campinas, Cx. Postal 6109, Campinas, SP 13081-862, Brazil. E-mail: wds@unicamp.br

In the present study the repetitive extragenic palindromic (REP) polymerase chain reaction (PCR) technique was used to establish the clonal variability of 49 avian Escherichia coli (APEC) strains isolated from different outbreak cases of septicemia $(n=24)$, swollen head syndrome $(n=14)$ and omphalitis $(n=11)$. Thirty commensal strains isolated from poultry with no signs of these illnesses were used as control strains. The purified DNA of these strains produced electrophoretic profiles ranging from 0 to 15 bands with molecular sizes varying from $100 \mathrm{bp}$ to $6.1 \mathrm{~kb}$, allowing the grouping of the 79 strains into a dendrogram containing 49 REP-types. Although REP-PCR showed good discriminating power it was not able to group the strains either into specific pathogenic classes or to differentiate between pathogenic and non-pathogenic strains. On the contrary, we recently demonstrated that other techniques such as ERIC-PCR and isoenzyme profiles are appropriate to discriminate between commensal and APEC strains and also to group these strains into specific pathogenic classes. In conclusion, REP-PCR seems to be a technique neither efficient nor universal for APEC strains discrimination. However, the population clonal structure obtained with the use of REP-PCR must not be ignored particularly if one takes into account that the APEC pathogenic mechanisms are not completely understood yet.
\end{abstract}

INDEX TERMS: Avian Escherichia coli, typing, REP-PCR.

RESUMO.- [Tipificação de amostras aviárias patogênicas de Escherichia coli pela REP-PCR.] A técnica de REP (Repetitive extragenic palindrome)-PCR foi utilizada para avaliar a variabilidade genética de 49 amostras de Escherichia coli patogênicas para aves (APEC), isoladas de aves de corte (frangos) em diferentes surtos de septicemia $(\mathrm{n}=24)$, síndrome da cabeça inchada $(n=14)$ e onfalite $(n=11)$. Trinta amostras comensais, isoladas de frangos sem sinais de doença, foram utilizadas como

\footnotetext{
${ }^{1}$ Received on July 14, 2005.

Accepted for publication on September 12, 2005.

2 Depto Microbiologia e Imunologia, Instituto de Biologia, Cx.Postal 6109, Universidade Estadual de Campinas (Unicamp), Cidade Universitária Zeferino Vaz s/n, Barão Geraldo, Campinas, SP 13081-862, Brazil. *Author for correspondence. E-mail: wds@unicamp.br

${ }^{3}$ Depto Microbiologia, Instituto de Ciências Biomédicas II, Av. Prof. Lineu Prestes 1374, $2^{\circ}$ Andar, Universidade de São Paulo (USP), São Paulo, SP 05508-900, Brazil.

${ }^{4}$ Depto Biologia Celular, Molecular e Bio-Agentes Patogênicos, Av. dos Bandeirantes 3900, Faculdade de Medicina de Ribeirão Preto, Universidade de São Paulo, Ribeirão Preto, SP 14049-900, Brazil.
}

controle. A análise do perfil eletroforético obtido por reação de REP-PCR utilizando DNA purificado das amostras evidenciou a amplificação de 0 a 15 bandas de DNA com pesos moleculares variando entre $100 \mathrm{pb}$ e $6.1 \mathrm{~Kb}$. A análise deste padrão permitiu a construção de um dendrograma demonstrando o agrupamento das 79 amostras em 49 perfis distintos. Embora a técnica de REP-PCR tenha apresentado grande poder discriminatório, as amostras patogênicas e não patogênicas não foram discriminadas entre si assim como não foi observado o agrupamento de amostras causadoras do mesmo tipo de doença. Por outro lado, demonstramos recentemente que outras técnicas tais como ERIC-PCR e a análise de isoenzimas foram eficientes quando utilizadas para esta mesma finalidade. Concluindo, REP-PCR parece não ser uma técnica eficiente e universal para discriminar entre amostras APEC. Porém, a estrutura clonal populacional obtida com o uso de REP-PCR não deve ser desprezada, particularmente se considerarmos que os mecanismos de patogenicidade de APEC ainda não são completamente conhecidos.

TERMOS DE INDEXAÇÃO: Escherichia coli aviária, tipificação, REP-PCR. 


\section{INTRODUCTION}

In poultry, the gram-negative bacterium Escherichia coli is an important cause of diseases resulting in serious economic losses to the poultry industry (Gross 1994). These strains are designated avian pathogenic E. coli (APEC) (Dho-Moulin \& Fairbrother 1999) and the diseases they cause are mainly septicemia, swollen head syndrome, omphalitis, cellulitis, yolk-sac infection and respiratory tract infections (Sojka \& Carnaghan 1961, Morley \& Thomson 1984, Randall et al. 1984). It has been proposed that some of the above mentioned diseases such as septicemia and swollen head syndrome start as secondary infections triggered by an initial Mycoplasma or viral infection followed by an invasive phase (Gross 1961, Aycard \& Lafont 1969, Dho \& Lafont 1982, Morley \& Thomson 1984). Omphalitis appears to be initiated by the bacterium actively crossing the egg barriers during the laying process or during incubation (Gross 1994) and in this case such types of bacteria would act just as opportunistic agents (Silveira et al. 2002a).

Several studies have been conducted in an attempt to understand the pathogenic mechanisms and virulence factors expressed by these strains (reviewed in Dho-Moulin \& Fairbrother 1999 and La Ragione \& Woodward 2002). Although many pathogenic factors of APEC strains were described (Fantinatti et al. 1994, Silveira et al. 1994, Gomis et al. 1997, Pourbakhsh et al. 1997a,b, Janben et al. 2001, Silveira et al. 2002a) many not yet described genes or virulence factors could probably be involved.

The discovery that prokaryotic genomes contain repeated sequences such as the repetitive extragenic palindrome (REP), or palindromic unit (PU) sequence (Higgins et al. 1982, Gilson et al. 1984), and the enterobacterial repetitive intergenic consensus (ERIC) sequence (Hulton et al. 1991) has expanded the molecular biology tools that are available to assess the clonal variability of many bacterial strains including Escherichia coli (Versalovic et al. 1991, Dalla-Costa et al. 1998). These molecular techniques are based on the use of primers homologous to these sequences that after PCR reaction generate a pattern of amplified bands specific for each isolate (Versalovic et al. 1991). Other molecular techniques such as Ribotyping and Isoenzyme profile have also been used to evaluate the clonality of avian $E$. coli (Silveira et al. 2003).

Recently it has been demonstrated that ERIC-PCR and Isoenzyme analysis are suitable for discrimination between commensal and APEC strains and also to group these strains into specific pathogenic classes (Silveira et al. 2002b, 2003).

The purpose of the present study was to evaluate if REP-PCR, a typing method using REP sequences as targets for PCR amplification, are also useful for studies of the clonal structure of APEC. The same APEC and commensal strains previously analyzed by ERIC-PCR and Isoenzyme profiles were here evaluated. All the strains were isolated in Brazil and are responsible for different diseases (septicemia, swollen head syndrome and omphalitis) of chickens. The commensal E. coli strains were isolated from the gastrointestinal tract of adult birds showing no clinical signs of these diseases and were used as control. Most of these strains were previously investigated for the presence of pathogenic traits and for pathogenicity in the one day-old-chicks assay (Silveira et al. 2002b).

\section{MATERIALS AND METHODS}

Bacterial strains. Twenty-four septicemic (S), 14 swollen head syndrome $(\mathrm{H})$ and 11 omphalitis $(\mathrm{O})$ Escherichia coli strains isolated from different outbreaks, and 30 commensal strains $(\mathrm{N})$ isolated from foals showing no signs of any of the above diseases and belonging to the Laboratory of Microbial Molecular Biology, DMI, UNICAMP, were studied in the present investigation. With the exception of commensal strains that were isolated from two different ranches located at least $50 \mathrm{Km}$ apart, all the other strains were obtained from different outbreaks occurred in different regions of Brazil (Table 1). For each case, three colonies were isolated and from those, which had the same plasmid and antimicrobial drugs resistance profiles, just one strain was used to make a frozen stock. Strains were identified as Escherichia coli by biochemical tests. Strains from septicemic cases were isolated from liver, air sacs and lung; swollen head syndrome strains were isolated from infraorbitary sinuses and onphalitis strains were isolated from the yolk sacs of one-day-old chicks; commensal strains were collected from cloacae region. All strains were kept at $70^{\circ} \mathrm{C}$ in $\mathrm{LB}$ medium containing $15 \%$ glycerol to avoid recombination events and plasmid losses.

Table 1. Escherichia coli strains used in the present study

\begin{tabular}{ccc}
\hline Pathogenic process & Strain (n) & Origin \\
\hline Omphalitis (O) & 11 & São Paulo State \\
Septicemia (S) & 12 & Paraná State \\
Septicemia (S) & 12 & Minas Gerais State \\
Swollen Head Syndrome (H) & 15 & São Paulo State \\
Commensal (N) & 15 & São Paulo State, Ranch 1 \\
& 15 & São Paulo State, Ranch 2
\end{tabular}

Extraction of genomic DNA. Genomic bacterial DNA was extracted as described by Van Soolingen et al. (1991). Extracted DNA was resuspended in TE buffer plus $10 \mathrm{mg} / \mathrm{ml}$ of RNAse and its integrity after extraction was determined using $0.7 \%$ agarose gels in TE buffer as described by Sambrook et al. (1989).

REP-PCR conditions and primers. REP-PCR primer sequences: REP1R-I, 5'-IIIICGICATCIGGC-3' and REP2-I. 5'-ICGICTTATCIGGCCTA-3' and the PCR reaction conditions were as described by Versalovic et al. (1991), in a final volume of $50 \mu \mathrm{l}$, with slight modifications as follows: an initial denaturation $\left(94^{\circ} \mathrm{C}, 7 \mathrm{~min}\right)$ followed by 30 cycles of denaturation $\left(90^{\circ} \mathrm{C}\right.$, $30 \mathrm{sec})$, annealing $\left(40^{\circ} \mathrm{C}, 1 \mathrm{~min}\right)$, and extension $\left(72^{\circ} \mathrm{C}, 8 \mathrm{~min}\right)$ with a single final extension $\left(72^{\circ} \mathrm{C}, 15 \mathrm{~min}\right)$. The size of the amplified fragments was visualized by electrophoresis in submersed agarose gel (1.5\%) using $100 \mathrm{bp}$ and $1 \mathrm{~kb}$ DNA markers (Life Technologies) as standards. The PCR for each strain was performed in three separate experiments to confirm the pattern of amplified bands.

Agarose gel electrophoresis. Agarose (1.5\%) gel electrophoresis was performed as described by Sambrook et al. (1989).

Fingerprint analyses. REP fingerprints of amplified DNA fragments obtained by agarose gel electrophoresis were recorded. The presence of a given band was coded as 1 and the absence of a given band was coded as 0 in a data matrix and analyzed using the Popgene software (Version 1.31) (Yeh et al. 1999). Dendrograms of dissimilarity were constructed for each case.

\section{RESULTS}

A total of 79 Escherichia coli strains isolated from birds were studied. Of these, 49 were obtained from birds showing clinical signs of septicemia $(n=24)$, swollen head syndrome $(n=14)$, or omphalitis $(n=11)$ and 30 strains, termed commensal, were isolated from the 


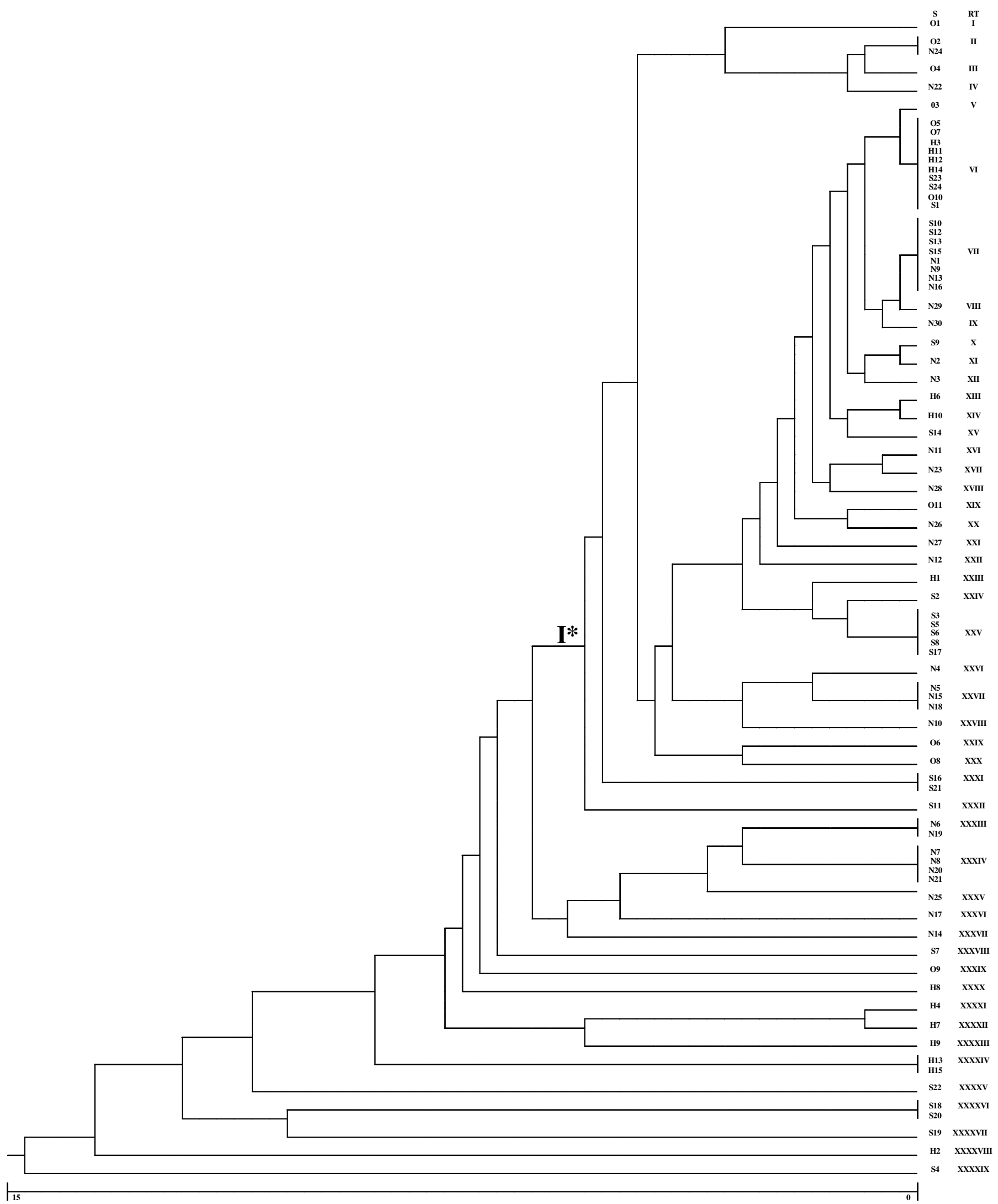

Fig.1. Dendrogram of dissimilarity showing the genetic distance of APEC and commensal Escherichia coli strains based on REP-PCR analyses ("Cluster I). 
cloacae of poultry showing no signs of any kind of the above diseases. All strains were studied in terms of the electrophoretic profiles of their DNA fragments obtained after PCR amplification using specific primers for REP elements. The DNA amplification of the $E$. coli strain was reproducible in the three amplifications experiments performed and the fingerprinting generated distinct amplification bands ranging in size from $100 \mathrm{bp}$ to $6.1 \mathrm{~kb}$ (data not shown). The obtained profiles allowed the grouping of the 79 strains into 49 REP-types (Fig.1) ranging from 0 to 15 bands, resulting in a dendrogram of high polymorphism but with a degree of dissimilarity not exceeding $15 \%$.

Among all the clusters obtained, one (cluster I, Fig.1) comprised $72.15 \%$ of all studied strains including $79.2 \%, 90.9 \%$, $50 \%$ and $70 \%$ of septicemic, omphalitis, swollen head syndrome and commensal strains, respectively.

It was possible to observe that although many strains responsible for causing the same type of disease had total genomic identity by this technique, strains isolated from birds suffering from different types of diseases also had total or even a very close genomic identity.

\section{DISCUSSION}

The initial works describing the clonal structure of Escherichia coli populations were those published by Selander \& Levin (1980) and Achtman et al. (1983). The most commonly used biochemical method to characterize bacterial populations is multilocus enzyme electrophoresis (Selander et al. 1986) and among the molecular genetic fingerprinting techniques, pulsed field gel electrophoresis (PFGE), restriction fragment length polymorphism (RFLP) and Multilocus sequence typing (MLST) are considered to be the most accurate and reproducible ones (Olive \& Bean 1999, Chansiripornchai et al. 2001, Urwin \& Maiden 2003). PFGE, RFLP and MLST analysis require relatively large amounts of DNA are time consuming and require expensive equipment, thus being unsuitable for most laboratories that work with bacterial populations.

Other molecular techniques such as random amplification of polymorphic DNA (RAPD), repetitive extragenic palindromic sequences (REP) and enterobacterial repetitive intergenic consensus (ERIC) (Welsh \& McClelland 1990, Versalovic et al. 1991, Silveira et al. 2002b) use less expensive equipment and can analyze the data within one day of work.

The 79 avian Escherichia coli strains analyzed in the present study (Fig.1) were found to have a high degree of polymorphism upon REP analysis, in agreement with the results obtained by another Brazilian group (De Moura et al. 2001) and by other groups either with RAPD (Chansiripornchai et al. 2001) or with multilocus enzyme electrophoresis (Achtman et al. 1983, Selander et al. 1986, Silveira et al. 2003) and ERIC-PCR (Silveira et al. 2002b). However, our results are different from those obtained by De Moura et al. (2001) that found similar discrimination power between REP and ERIC-PCR.

When we look at the distribution of the strains inside the constructed dendrogram we can see that, although REP-PCR has discriminating capacity, there is no real separation according to the type of disease from which the strain was isolated. The REPPCR also did not discriminate between commensal and pathogenic strains. These results are different of those recently described by us using ERIC and Isoenzyme profile (Silveira et al. 2002b, 2003). Using these techniques we were able to discriminate between these $E$. coli, separating pathogenic and non-pathogenic strains into different clusters and grouping most of the strains according to the disease origin. Thus, our results indicated that REP-PCR per se is less affective than ERIC and Isoenzyme profiles to group APEC strains according to the pathogenic process.

Our results also agree with others studies that compared REP-PCR with others typing methods. Dombek et al. (2000), for example, demonstrated that REP-PCR was less effective than Boxderived fingerprints to discriminate among $E$. coli isolated from humans and others animals, including chickens. In another study, Lipman et al. (1995), comparing the ability of fingerprints performed with REP and ERIC primers, concluded that the last was more effective in differentiating among $E$. coli strains from cows with clinical mastitis.

Based on the present results, we suggest that REP-PCR can discriminate between APEC strains. However, when employed for the genomic characterization of APEC populations, this technique is not effective for these strains types.

The discrepancies between our data and those obtained by de Moura et al. (2001) regarding the use of REP-PCR for APEC discrimination could be explained by genetic variability between different bacterial populations. In fact, the strains here analyzed and those studied by de Moura et al. (2001) are not related epidemiologically. In conclusion, in the light of these contradictory results, we believe that REP-PCR is not a universal and reliable technique to discriminate between APEC strains. Our data suggest that other techniques as such as ERIC-PCR and isoenzyme profiles should be used in place of REP-PCR for APEC discrimination.

There is still much to be explored for a better comprehension of the APEC pathogenesis. Thus, the genetic relationship between these strains obtained with REP-PCR must not be ignored. Maybe, in the near future, when the mechanisms of pathogenicity and the virulence factors of avian pathogenic $E$. coli strains come to be better understood, the meaning of the APEC population structure achieved with this technique could be better comprehended.

Acknowledgments.- The study was supported by grants ( $n^{\circ} 03 / 08407-0$ and $n^{\circ}$ 99/04097-0) from The Foundation for the Support of Research of the State of São Paulo (FAPESP) and (no 303301/2002-3) from The National Council for Scientific and Technological Development (CNPq).

\section{REFERENCES}

Achtman M., Mercer A., Kusecek B., Pohl A., Heuzenroeder M., Aaronson W., Sutton A. \& Silver R.P. 1983. Six widespread bacterial clones among Escherichia coli $\mathrm{K} 1$ isolates. Infect. Immun. 39:315-335.

Aycard J. \& Lafont J.P. 1969. Donnés recents sur l'étiologie et l'épizootologie de la mycoplasmose du poulet. Consequénces prophylactiques. Bull. Off. Int. Epizoot. 72:351-380.

Chansiripornchai N., Ramasoota P., Sasipreyajan J. \& Sevenson S.B. 2001. Differentiation of avian Escherichia coli (APEC) strains by random amplified polymorphic DNA (RAPD) analysis. Vet. Microbiol. 80:75-83.

Dalla-Costa L.M., Irino K., Rodrigues J., Rivera I.N.G. \& Trabulsi LR. 1998. Characterization of diarrhoeagenic Escherichia coli clones by ribotyping and ERIC-PCR. J. Med. Microbiol. 47:227-234.

De Moura A.C., Irino K. \& Vidotto M.C. 2001. Genetic variability of avian 
Escherichia coli strains evaluated by enterobacterial repetitive intergenic consensus and repetitive extragenic palindromic polymerase chain reaction. Avian. Dis. 45:173-181.

Dho M. \& Lafont J.P. 1982. Escherichia coli colonization of the trachea in poultry: Comparison of virulent and avirulent strains in gnotoxigenic chickens. Avian. Dis. 26:787-797.

Dho-Moulin M. \& Fairbrother J.M. 1999. Avian pathogenic Escherichia coli (APEC). Vet. Res. 30:299-316.

Dombek P.E., Johnson L.K., Zimmerley S.T. \& Sadowsky M.J. 2000. Use of repetitive DNA sequences and the PCR to differentiate Escherichia coli isolates from human and animal sources. Appl. Environ. Microbiol. 66:2572-2577.

Fantinatti F., Silveira W.D. \& Pestana de Castro A.F. 1994. Characteristics associated with pathogenicity of avian septicaemic Escherichia coli strains. Vet. Microbiol. 41:75-86.

Gilson E., Clément J.M., Brutlag D. \& Hofnung M. 1984. A family of dispersed repetitive extragenic palindromic DNA sequences in Escherichia coli. EMBO J. 3:1417-1421.

Gomis S.M., Watts T., Riddell C., Potter A.A. \& Allan B.J. 1997. Experimental reproduction of Escherichia coli cellulitis and septicemia in broiler chickens. Avian. Dis. 41:234-240.

Gross W.B. 1961. The development of “air sac disease”. Avian. Dis. 5:431439.

Gross W.B. 1994. Diseases due to Esherichia coli in poultry, p.237-259. In: Gyles CL (ed.) Escherichia coli in Domestic Animals and Humans. CAB International, Wallingford, UK. Higgins C.F., Ames G.F.L., Barnes W.N., Clément J.M. \& Hofnung M 1982. A novel intercistronic regulatory element of prokaryotic operons. Nature 298:760-762.

Hulton C.S., Higgins C.F. \& Sharp P.M. 1991. ERIC sequences: a novel family of repetitive elements in the genomes of Escherichia coli, Salmonella typhimurium and other enterobacteria. Mol. Microbiol. 5:825-834.

Janben T., Schwerz C., Preikschat P., Voss M.H., Philipp C. \& Wieler L.H. 2001. Virulence-associated genes in avian pathogenic Escherichia coli (APEC) isolated from internal organs of poultry having died from colibacillosis. Int. J. Med. Microbiol. 291:371-378.

La Ragione, R.M. \& Woodward, M.J. 2002. Virulence factors of Escherichia coli serotypes associated with avian colisepticaemia. Res. Vet.Sci. 73:2735 .

Lipman L.J., de Nijs A., Lam T.J. \& Gaastra, W. 1995. Identification of Escherichia coli strains from cows with clinical mastitis by serotyping and DNA polymorphism patterns with REP and ERIC primers. Vet. Microbiol. 43:13-19.

Morley A. J. \& Thomson D.K. 1984. Swollen head syndrome in broiler chickens. Avian. Dis. 28:238-243.

Olive D.M. \& Bean P. 1999. Principles and applications of methods for DNAbased typing of microbial organisms. J. Clin. Microbiol. 3:1661-1669.

Pourbakhsh S.A., Boulianne M., Martineau-Doizé B., Dozois C.M., Desautels
C. \& Fairbrother J.M. 1997a. Dynamics of Escherichia coli infection in experimentally inoculated chickens. Avian. Dis. 41:221-233.

Pourbakhsh S.A., Dho-Moulin M., Brée A., Desautels C., Martineau-Doize B. \& Fairbrother J.M. 1997b. Localization of the in vivo expression of $P$ and F1 fimbriae in chickens experimentally inoculated with pathogenic Escherichia coli. Microbiol. Pathog. 22:331-41.

Randall C.J., Meakins P.A., Harris M.P. \& Watt D.J. 1984. A new skin disease in broilers? Vet. Rec. 114:246.

Sambrook J., Fritsch E.F. \& Maniatis T. 1989. Molecular Cloning: A Laboratory Manual. 2nd ed. Cold Spring Harbor Laboratory Press, NY. 1584p.

Selander R.K. \& Levin B.R. 1980. Genetic diversity and structure in Escherichia coli populations. Science 210:545-547.

Selander R.K., Gaugant D.A., Ochman H., Musser J.M., Gilmour M.N. \& Whittam T.S. 1986. Methods of multilocus enzyme electrophoresis for bacterial population genetics and systematics. .Appl .Environ. Microbiol. 51:873-884

Silveira W.D., Fantinatti F. \& Pestana de Castro A.P. 1994. Transposon mutagenesis and membrane protein studies in avian colisepticaemic Escherichia coli strain. Braz. J. Genet. 17:9-14.

Silveira W.D., Ferreira A., Brocchi M., Hollanda L.M., Pestana de Castro A.F., Yamada A.T. \& Lancellotti M. 2002a. Biological characteristics and pathogenicity of avian Escherichia coli strains. Vet. Microbiol. 85:47-53.

Silveira W.D., Ferreira A., Lancellott M., Barbosa I., Leite D.S., Pestana de Castro A.F. \& Brocchi M. 2002b. Clonal relationships among avian Escherichia coli isolates determined by enterobacterial repetitive intergenic consensus (ERIC)-PCR. Vet. Microbiol. 89:323-328.

Silveira W.D., Lancellotti M., Ferreira A., Solferini V.N., Pestana de Castro A.F., Stehling E.G. \& Brocchi M. 2003. Determination of the Clonal Structure of Avian Escherichia coli Strains by Isoenzyme and Ribotyping Analysis. J. Vet. Med. B Infect. Dis. Vet. Public Hlth 50:63-69.

Sojka W.J. \& Carnaghan R.B.A. 1961. Escherichia coli infection in poultry. Res. Vet. Sci. 2:340-352.

Urwin R. \& Maiden M.C. 2003. Multi-locus sequence typing: a tool for global epidemiology. Trends. Microbiol. 11:479-487.

Van Soolingen D., Hermans P.W.M., Hass P.E.W., Sool D.R. \& Van Embden J.D.A. 1991. The occurrence and stability of insertion sequences in Mycobacterium tuberculosis complex strains; evaluation of IS-dependent DNA polymorphism as a tool in the epidemiology of tuberculosis. J. Clin. Microbiol. 29:2578-2586.

Versalovic J., Koeuth T. \& Lupski J.R. 1991. Distribution of repetitive DNA sequences in eubacteria and application to fingerprinting of bacterial genomes. Nucleic. Acid. Res. 19:6823-6831.

Welsh J. \& McClelland M. 1990. Fingerprinting genomes using PCR with arbitrary primers. Nucleic. Acids Res. 18:7213-7218.

Yeh F.C., Yang R.C. \& Boyle T. 1999. Popgene version 1.31. Microsoft Windows-based freeware for Population Genetic Analysis. (http:// www.ualberta. ca/ fyeh/) 